\title{
Ancient Inscriptions between Citizens and Scholars: The Double Soul of the EAGLE Project
}

\author{
Silvia Orlandi
}

Sapienza University of Rome

\begin{abstract}
The mission of the European project EAGLE (Europeana network of Ancient Greek and Latin Epigraphy) is 'to make ancient inscriptions accessible'. This means not only to create a useful research tool for classical scholars so that they can find online high quality information about epigraphic texts and artefacts, but also to allow a broad public — consisting of students, teachers, tourists, curious and interested citizens - to understand and appreciate inscribed monuments, even if they are written in ancient languages and alphabets. Digital technologies can help not only to preserve, at least in a virtual archive, our archaeological heritage that is often in danger, but also to improve knowledge of, and therefore respect for said heritage. The EAGLE project has given particular importance to this 'civic' aspect, developing two applications (a mobile app, that uses an image based recognition system, and a storytelling application), which show that even ancient inscriptions are not so out of reach as they seem, and can also be fun.
\end{abstract}

\section{Preliminary Thoughts}

In her interview with the Huffington Post on 31 January 2014, Perry Hewitt, Harvard University's Chief Digital Officer, has illustrated the 10 Best Practices

How to cite this book chapter:

Orlandi, S. 2016. Ancient Inscriptions between Citizens and Scholars: The Double Soul of the EAGLE Project. In: Bodard, G \& Romanello, M (eds.) Digital Classics Outside the Echo-Chamber: Teaching, Knowledge Exchange \& Public Engagement, Pp. 205-221. London: Ubiquity Press. DOI: http://dx.doi.org/10.5334/bat.l. License: CC-BY 4.0. 
for dealing with digital transformation. ${ }^{1}$ As the scientific coordinator of a project which focusses on digital technologies, I carefully read this list. One point in particular caught my attention: 'Don't do digital for the sake of digital: figure out how digital impedes or advances your key objectives and goals'.

The enormous growth of projects, papers, blogs and other initiatives being published on the Web has put at everyone's disposal a huge (and evergrowing) amount of data, documents and images. Sometimes these data are of high quality; sometimes they are not completely reliable and sometimes simply flawed or out of date. This means that having access to a larger amount of information, in a manner that is much faster than before, does not necessarily translate into an improvement of our knowledge, given the need to check and critically appraise what we find online and to collect and compare materials often scattered in different and disconnected online archives. To make digital projects actually useful and effective for meaningful cultural development, better and ever-improving technology undoubtedly helps, but it is not enough: much depends on how content is conceived and prepared in order to be made available, as well as on several crucial choices made with regard to the target audience and to the scenarios of access and of use of said content. In short, one must carefully consider the overall vision (or lack thereof) that lies behind every digital project.

A solid concept indeed lies at the very root of the EC-funded project Europeana Network of Ancient Greek and Latin Epigraphy (EAGLE), ${ }^{2}$ that forms the background of what is discussed in this essay. The latter was born in 2003 as a federation of four epigraphic databases that had agreed to make their geographically separated collections accessible through a common online interface (i.e. a single portal). ${ }^{3}$ Most importantly, the four partners shared the same idea of what an inscription is and what information we need in order to deal with it: epigraphic documents should not be regarded as mere texts, but as inscribed objects and monuments within specific topographic and geographic contexts. Each inscription should be presented and studied as a whole, examining material and archaeological characteristics along with textual and philological aspects. EAGLE was founded on the bedrock of this approach.

To reach a goal of this kind, scanning a book and quickly filling in just a couple of metadata fields is not enough: both the epigraphic text and the remaining information must be ingested carefully and critically. This means checking the text, whenever possible, against the original stone engraving, or at least against a good photo or drawing of it, and giving the user the chance to accomplish the same. This is not easy, and not quick, but a good and reliable documentary corpus is the necessary starting point of every research work. Therefore, it is worth investing time and energy in order to produce it. The only way to ensure both quality of content and quantity of items is by bringing together different people, projects, institutions, which for their knowledge and experience are in the best position to provide high quality content, and letting them work together towards a common goal. In other words, in order to become a really 
useful resource, a digital project must be structured and organised according to the wills and needs of experts in the field.

\section{On the Usefulness of Digital Resources-an Example}

To give an idea of how such a collaboration can result in more informed and richer digital editions, I have deliberately chosen the smallest possible example.

Among the hundreds of inscriptions found at the beginning of the twentieth century in Rome, there is a fragment of a marble slab, which was dug up from a vast necropolis site between via Salaria and via Pinciana. The fragment is thus featured in the sixth volume of Corpus Inscriptionum Latinarum (Figure 1):

Reproducing this apparently meaningless sequence of letters faithfully but uncritically would add a new item to our digital archive, but it would be of no help to an in-depth study of the context to which this fragment used to belong or to a development of its historical importance. Additional data that complement the text with other layers of information (such as an image of the monument and other details about its spatial and social context) help lift the veil of ambiguity. Thanks to the work of American colleagues who are working on a digital edition of all the Classic Greek and Latin inscriptions hosted by US collections, we now learn that this fragment is preserved in the J.B. Speed Art Museum of Louisville, Kentucky, and its photograph, which is also available on line, tells us that it is the left part of a columbarium (niche for funerary urn) inscription. ${ }^{4}$

In turn, putting these two resources in relation with one another allowed us to infer three things: firstly that small columbaria were part of the ancient landscape of the funerary area between via Salaria and via Pinciana; secondly that the inscription can be dated to the beginning of the 1 st century $\mathrm{AD}$, when such artefacts were mostly used; and thirdly, that the dead person mentioned in the text is probably a member of the lower classes of Roman society, for which this kind of funerary monuments were conceived. Thanks to the additional information collected through different sources, we can also go beyond the simple reading of the surviving letters and propose an integration and an

\section{5}

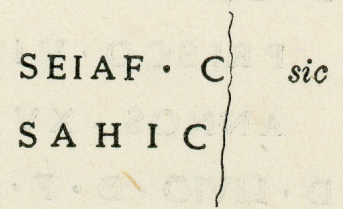

Figure 1: CIL, VI 33645. 
interpretation of the text, which is actually the epitaph of a woman, whose family name in genitive, Seiae, was written in the wrong form 'Seiaf' because of a mistake of the stonecutter. Seiae was probably followed by the cognomen of the dead person, which was lost, together with the right part of the stone, and by the formula 'ossa hic sita sunt' ('Her bones lay here'), which is typical of this kind of text and which can be completely restored. Therefore the digital form of our inscription in the Epigraphic Database Roma goes beyond the simple reproduction of the corresponding CIL edition, allowing a more interpretative and meaningful transcription of the text: Seia $e^{\top} C[---o s] / s a$ hic $[$ sita sunt $] .{ }^{5}$

This is but a small example of the kind of achievements that collaboration between researchers, coupled with a critical approach to ancient sources, can give. If we apply this method systematically to every possible epigraphic document, the result is a large digital archive to which many scholars contribute by providing high quality content, in order to build together a real state-of-the-art research asset.

Moreover, the application of data mining methods may help to reveal interesting relationships among, for instance, linguistic style, positioning and dating of inscriptions, thus creating new links between different pieces of data, and trying to give 'quantitative measurements' of intuition. ${ }^{6}$

\section{EAGLE and Europeana: Online Digital Resources for Everyone}

The idea of a collaborative project to share both data and knowledge about inscriptions led to the original EAGLE federation in 2003, as well as to the 'new' EAGLE project, which kicked off in 2012. In fact, 2012 is the year when EAGLE 'grew up'-so to speak - to become a consortium of 19 partners from 12 different European countries. ${ }^{7}$ The new consortium constitutes what the European Commission calls a Best Practice Network, aimed at making accessible most of the ancient Greek and Latin inscriptions through a single Web portal, as well as through Europeana, the European digital library. ${ }^{8}$

Within the EAGLE consortium, besides the four 'historical' members (EDB, EDH, EDR and HEpOl), there are new important content providers, including some of the most important European projects in digital epigraphy-such as The Last Statues of Antiquity project by Oxford University, Ubi erat lupa (based in Salzburg and collecting material from different Eastern European countries), the new version of the existing PETRAE project, which has put on line the inscriptions of Roman Aquitania and not forgetting the key role played by the Arachne project, which is currently digitising the huge photographic archive and part of the library of the German Archaeological Institute.

All this content comes from different repositories with different architectures, interfaces and data structures. Hence, it must be first of all harmonised and aggregated according to a common metadata model in order to be made 
accessible through a single search tool. In this field, the technical partners of the EAGLE consortium have a fundamental importance, starting from the Catholic University of Leuven, whose task is to 'disambiguate' content coming from different archives but related to the same object. No less important is the role played by the IT staff working at CNR-ISTI in Pisa, as well as of Promoter, Gogate and QED Productions, three companies with a great deal of experience in EC-funded projects. Thanks to the concerted efforts of all these entities, EAGLE is becoming not only a large database of aggregated content, but alsoand this is perhaps one of its most interesting and promising aspects-a virtual platform over which other people and institutions sharing the same spirit of the EAGLE community can join the consortium and put at everyone's disposal the epigraphic content on which they are working. This in turn generates interesting synergies between different geographically separated institutions and people.

In other words, we are gradually moving from the idea of collecting large amounts of digital data that can be searched easily and quickly, to the idea of working in a digital environment; a world where collaboration and interoperability are the keywords for a real cultural (not only scientific) progress. To put it another way, the successful digital aggregation project is as much an inspiring operation of social and institutional engineering as it is a technical IT challenge.

This became clear when, for example, EAGLE signed a Memorandum of Understanding with the Pelagios consortium ${ }^{9}$ in order to share geographic information to improve the digital atlas of the ancient world, and also through the Cooperation Agreement with the project led by Alison Cooley and focused on the Latin inscriptions of the Ashmolean Museum, ${ }^{10}$ or when the EAGLE content was enriched by the thousands of English translations of Greek inscriptions provided by the Attic Inscriptions Online. ${ }^{11}$ In fact, the use of new technologies integrated in a virtual environment allows possibilities that are not limited to the academic world. A 'virtual environment' is by definition an open space, not an ivory tower that can be reached only by few scholars, but a room with open doors that can be entered by academics as well as by interested and curious people, not just 'customers' but users. ${ }^{12}$

A good example of what can be done collecting and making accessible primary sources of historical interest is given by the big Europeana 1914-1918 initiative-untold stories and official histories of WW1: a wide range and number of digital materials (letters, postcards, photographs, videos, audio files...) coming from both public and private archives, intended to be used to discover more about our past, learn history in a more interactive way, research new aspects of well-known events and above all share this knowledge with the whole community. To collect materials telling interesting stories about people, families and little communities (war nurses, chaplains, Old Etonians...) that escaped the attention of the great historians, different initiatives were taken and different engagement strategies were applied. Museums and libraries have organized 'Collection days', when letters, photos and other documents were physically collected in order to be digitized and put at disposal of the project. 
Registered users can also contribute any time through the page 'Add your story!' of the Europeana 1914-1918 website. ${ }^{13}$ Thousands of documents have been added, enriched and displayed in this way.

User engagement is, in fact, one of the key issues of every digital initiative that aims to bring a real improvement and a long term change in our culture and society. As many papers, lectures and interviews have recently underlined, no legal or political action to protect our cultural heritage is better than the involvement of the citizens, and respect can only rise from the consciousness of the importance of the past.

\section{Digital is also Useful for Preservation}

Ancient inscriptions are part of this cultural heritage and a fundamental source for our knowledge of classical civilizations. But at the same time, as all the relics of the ancient world, inscriptions-or what is left of them-are fragile and perishable: the majority of the millions of inscribed objects and monuments that were produced in the Classical world did not survive to this day. Indeed, most of the inscriptions that were still known to exist only a few centuries ago are now lost. To preserve this important heritage is therefore the first requirement and civic duty of a digital project like EAGLE, since past and present experiences teach us that:

\section{i) inscriptions can be destroyed.}

As we can read in the Corpus Inscriptionum Latinarum, the epitaph of a Roman soldier which had been found re-employed as a slab of the floor of the San Pietro in Vincoli church in Rome, got lost when troops occupied the church during the conflict against the papal army in the time of the Repubblica Romana in 1849 (anno 1849 coenobio a militibus occupato periit, vel certe ab eo inde tempore latet) (Figure 2). Hence, this fragment is known only thanks to a manuscript (CIL, VI 2597). ${ }^{14}$

Soldiers can be dangerous for cultural heritage not only in war actions, but also during their free time, as is witnessed by the history of an ancient inscription with bronze letters found in the floor of the Odeon in Pompeii at the end of the 18th-century (CIL, X 845). ${ }^{15}$ In the following years, some of the letters were stolen by soldiers visiting the archaeological site, and only some of them were given back to the custodians-as can be read in the comment of CIL, X 845 (Figure 3), before being almost completely lost today. ${ }^{16}$

More recently, on July 29th 1993, the San Giorgio al Velabro church in Rome was the target of a terrorist attack (Figure 4).

The inscriptions displayed in the portico were damaged and made inaccessible, as we can read in one of the entries of the supplementary volume of CIL, 
2597 fragmentum tabulae marmoreae. Nel rifare il pavimento di S. Pietro in Vincoli sotto il card. Galli mons. In bibliotheca coenobii S. Petri ad vincula anno 1842; anno 1849 coenobio a militibus occupato periit, vel certe ab eo inde tempore latet Rossr.

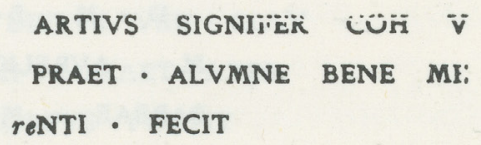

Descripsit de Rossi. Exhibent schedae Monsacrati in bibliotheca S. Petri ad vincula adservatae.

Figure 2: CIL, VI 2597.

VI edited in 2000 by Géza Alföldy: post pyroboli diruptionem ab hominibus terrorem excitantibus effectam (Figure 5). ${ }^{18}$

ii) Inscriptions can be stolen.

A fragment of one of the inscriptions of the Colosseum mentioning the senators who had the right of sitting in the first rows of the amphitheatre was the protagonist of a famous theft some years ago and mentioned by different newspapers. ${ }^{19}$ Beyond this, a large number of inscribed objects have become impossible to find, whilst sometimes some of them suddenly reappear on the antiquarian market. ${ }^{20}$ 


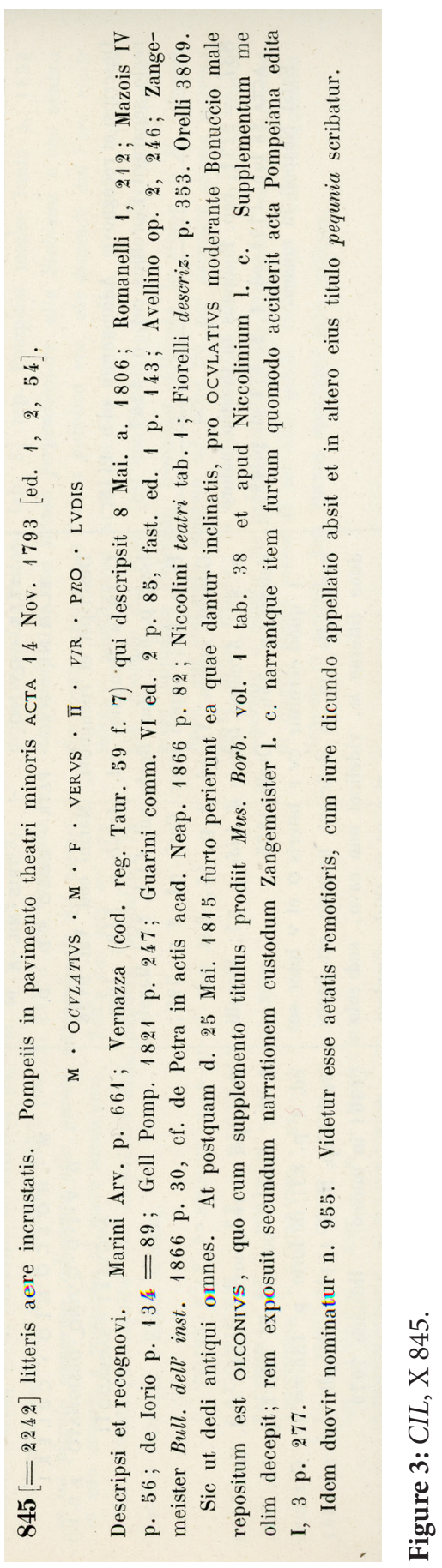




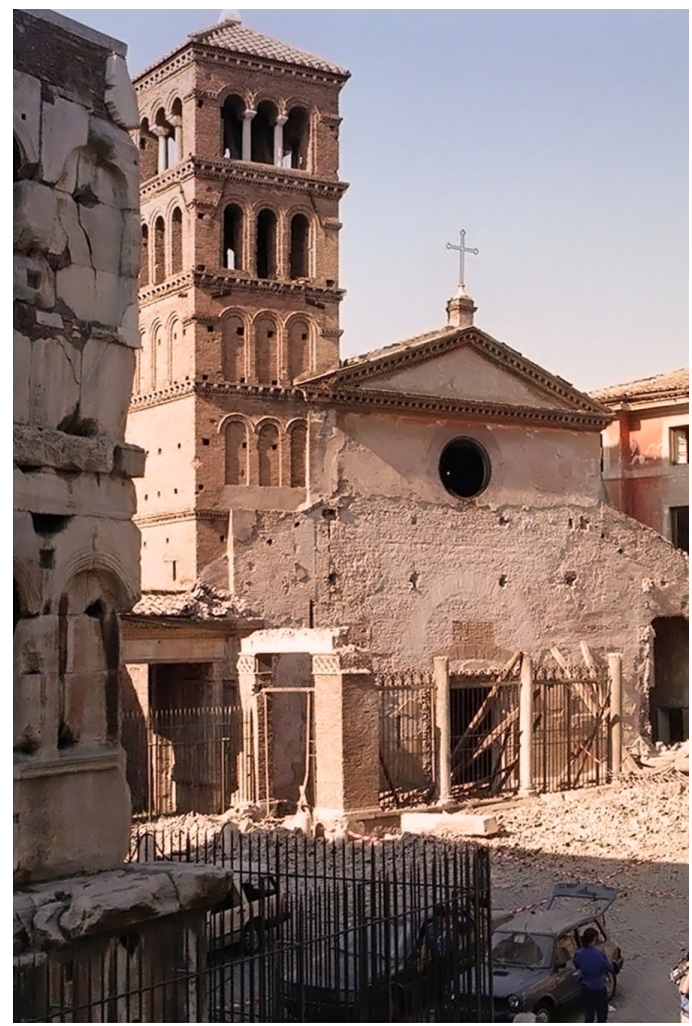

Figure 4: S. Giorgio al Velabro. Downloaded from beatopadrepuglisi.it. ${ }^{17}$

40718 (= 1123) tit. honorarius imperatoris

Tabula marmorea ex tribus partibus coniuncta undique fracta, in fronte caelo dolata $(30) \times(44) \times$ ?. Litt. 7 . In aede S. Georgii in Velabro $\langle$ Urbs $\mathrm{O} / \mathrm{P} 23\rangle$ descripsit iam Forcella. Extat ibid. a porta ecclesiae introeuntibus a sinistra parieti inserta, ubi descripsi a. 1987, recognovi a. 1989. Cum a. 1993 titulum denuo adire et im. phot. sumere volui, clausus erat aede post pyroboli diruptionem ab hominibus terrorem excitantibus effectam ex parte diruta et cancellis ferreis circumdata.

Fuit fere:

[Germanico maximo Sarmatico maximo] Persico ma[ximo Britannico maximo] Carpiç[o maximo, pont(ifici) $\max ($ imo)], [tribu]nicicia [potestate - - -]

Figure 5: CIL, VI 40718. 


\section{iii) Inscriptions can be damaged.}

Since the time when the Lanzichenecchi sacked Rome in 1527 and left visible traces of their passage on the frescos of Villa Farnesina, ${ }^{21}$ 'barbarians' of every age and place seemingly cannot resist the temptation to use walls and stones-no matter how ancient and valuable they are-to express their feelings and political opinions, providing useful materials for historians, but also inflicting sometimes irreversible damage to our cultural heritage. It is the case of an epitaph found and still displayed at the fifth mile of the via Appia (Figure 6), ${ }^{22}$ where the ancient inscription was temporarily covered by a modern 'graffito' insulting Rome's former major Francesco Rutelli.

In all the above instances, having the inscribed texts and the related images digitised and available through one of the repositories aggregated by EAGLE will ensure somehow their survival. Although this cannot prevent further future destruction of artefacts, at least it does increase our chances that information will not be lost, and therefore yields the possibility of reading and studying these documents, thus keeping-so to speak-an open window on our past.

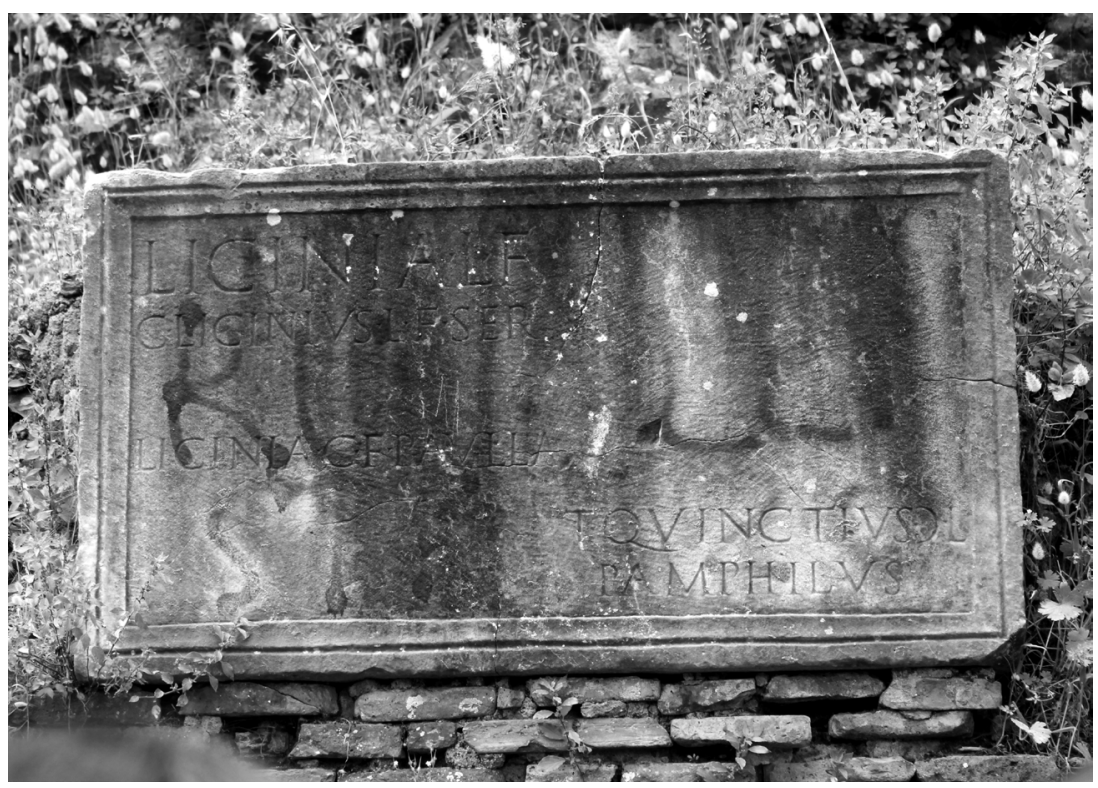

Figure 6: CIL, VI 21312. Photo Leonardo Radicioni, by kind permission of the Soprintendenza Speciale per il Colosseo, il Museo Nazionale Romano e l'Area archeologica di Roma. 


\section{Added Value of new Tools and new Media}

New technologies can help us not only to preserve the remains of ancient civilizations from damage and loss, but also to make them more visible, informative and valuable. ICT is playing an increasingly significant role in the way in which culture is perceived and appreciated by the public. Not by chance, according to one of the most famous travel websites, Tripadvisor, the most important 'attractions' in Rome, and one of the 'Top 25 destinations' are the domus under Palazzo Valentini, whose remains have been included in an underground walk full of suggestion, images, lights and sounds that transform a guided tour into an emotional, immersive experience. The narrative structure and the virtual reconstructions meet the needs and the expectations of the modern visitors, stimulating curiosity, amusement and interest at the same time. ${ }^{23}$ Why should we not learn from this experience and try to extend such an approach also to ancient inscriptions without being afraid of their apparent complexity?

In order to meet these needs, two flagship mobile apps have been foreseen as part of the EAGLE project:

- The Mobile Application, whose aim is to provide sightseers with on-thefly information about inscriptions: thanks to a visual recognition system, developed by the CNR-ISTI in Pisa and by Eureva in Paris, all that visitors have to do is take a photo with their smartphone of the inscription in which they are interested. The picture is sent to the EAGLE servers. There, a specific software will recognize the picture from within a database of selected inscriptions and will provide all the information associated with that picture. This image-based application overcomes the difficulty represented by texts written in ancient languages and alphabets and using often abbreviated forms typical of the 'epigraphic habit'. Moreover, this custom developed software can become the base of further developments that can use epigraphic content to reach a different type and level of public: scholars, casual users, tourists, children... In this way, without denying the complexity of this particular kind of cultural object, technology can help us not to abandon the idea of including ancient inscriptions in touristic routes and educational projects.

- The Storytelling Application, conceived to help professionals (teachers, students, writers, historians) to build stories starting from ancient inscriptions and using materials and information collected in different digital repositories and projects (not only EAGLE but also Perseus, Wikimedia Commons and the other members of the "Wikifamily", not forgetting what can be found in the social media like, for example, Flickr or Instagram). Starting from the preliminary assumption that behind every inscription there is an individual story - of a man, of a family or of a community-it's up to us to tell this story in a way that can be both creative and historically 
documented. The stories already collected in the specific repository of the EAGLE project website are a good example of what can be done with this material. ${ }^{24}$ The storytelling version of a group of inscriptions of the National Museum of Slovenia in Ljubljana has also found a more traditional form in a book recently published by M. Šašel Kos, The disappearing Tombstone and other stories. ${ }^{25}$

But, in this case as well, technology is just a possibility, and not a real resource for cultural development without a vision behind it. And the vision in this case is that, even if it may seem impossible, epigraphy can be fun. Now, as a video recently posted on You Tube has shown, curiosity and amusement can be the way to let people do willingly and happily what they know is important, but seems to be heavy and boring, like... taking the steps instead of the escalator. ${ }^{26}$

You can have fun with epigraphy chasing inscriptions in places where you would never expect to find them. Irene Somà, PhD student in Ancient History and one of the followers of the EAGLE project on Facebook, during a trip to Qasr al-Azraq in Jordan noticed an important bilingual (Greek and Latin) inscription bearing the names of the tetrarchs Diocletian and Maximian; she could not only identify it, ${ }^{27}$ but also found it mentioned in the novel 'The Seven Pillars of Wisdom' by Lawrence of Arabia and posted both the image of the stone and the passage of the book on the EAGLE Facebook webpage. ${ }^{28}$ Following this example, another novel, 'Isole' by Marco Lodoli, was posted on the same webpage ${ }^{29}$ because it contains a specific reference to an inscribed monument too: the long verse epitaph of the young Quintus Suplicius Maximus, who died at age 9 after having won a poetry contest, which was found (and is still visible, although in copy form) near Porta Salaria in Rome. ${ }^{30}$ Even a real estate advertisement can be used to discover or, better, rediscover an ancient dedication to the god Mithra, seen in the 17th-century by the scholar Lukas Holste during his epigraphic voyages, and since then considered lost. ${ }^{31}$ Actually, the stone is still immured exactly in the same country house where Holste saw it three centuries ago, as the web page of the real-estate agency proudly shows (Figure 7) and as Lucio Benedetti was so keen to find out. ${ }^{32}$

Films can also be an unexpected instance where you can find ancient inscriptions not necessarily recognised and used as such. For example, in a scene of Nell'anno del Signore, by Italian director Luigi Magni, an ecclesiastic tribunal chaired by cardinal Rivarola (here played by Ugo Tognazzi) stands behind a 'table' which is actually made of a large inscribed architrave. This is part of a dedication to the emperor Constantine and his sons, found and preserved in the Baths of Caracalla in Rome, ${ }^{34}$ where the scene was shot. The ancient text does not play any proper role in the film (although I cannot exclude a more or less conscious reference to the power of the ruling class), 


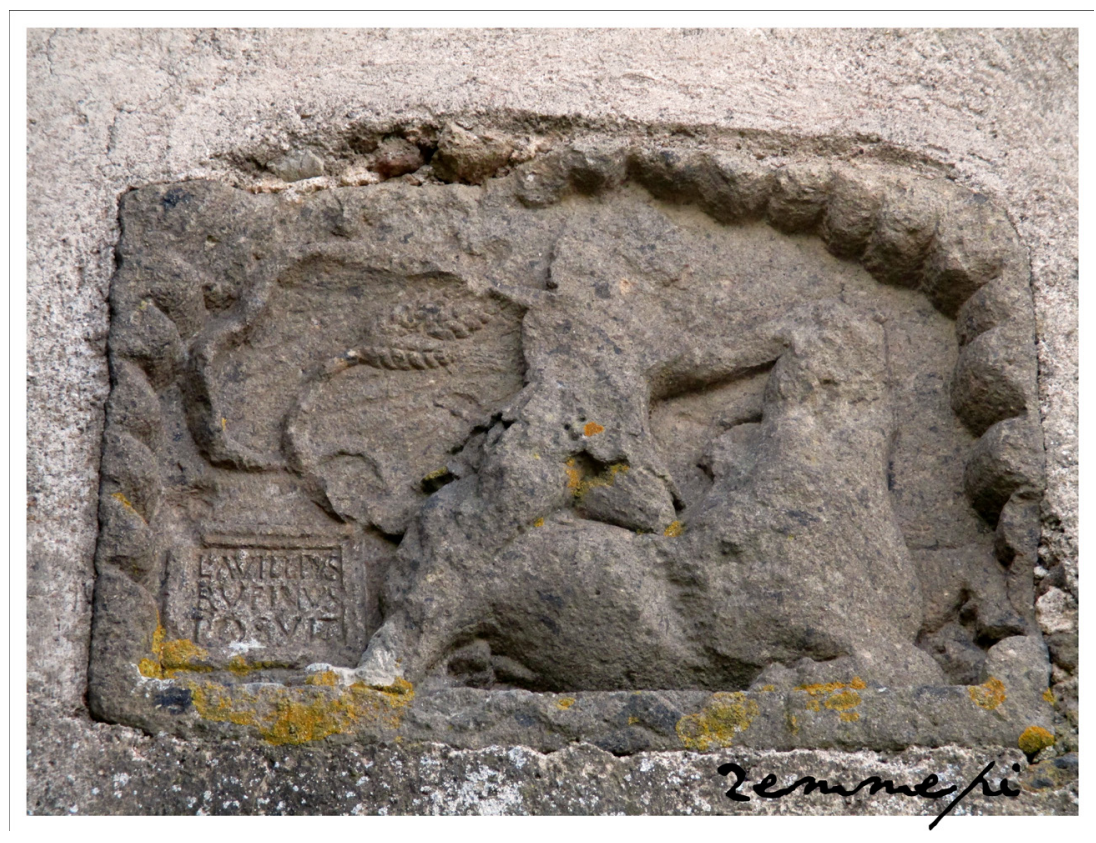

Figure 7: CIL, XI 3320. Photo downloaded from duemmepi.altervista.org. ${ }^{33}$

but its creative use in this scene is a very immediate way to show how, in a city like Rome, at any time, past and present always co-exist along each other.

On the other hand, in films based on ancient history or, more generally, set in the ancient world, one could expect that inscriptions should be a significant presence in the reconstruction of the urban landscape, as they actually were. A good choice is given, for example, by the Rome TV series, whose opening credits run over ancient walls completely covered by graffiti. ${ }^{35}$ But I must admit that, in most cases, inscriptions are not felt as an important element, and the results are often disappointing, as in Gladiator, where over the door of the training school for gladiators beside the Colosseum the attentive viewer reads 'Ludus magnus gladiatores', a text that amounts to grammatical nonsense. Or as in the film Agora, set in the ancient city of Alexandria, where the local Serapaeum proudly shows on its architrave a monumental inscription: 'M. Agrippa cos. tertium fecit', which is no less than... the inscription of the Pantheon in Rome! ${ }^{36}$

The aim of these observations is not to find all the 'errors' in Gladiator or in other historical movies, but rather to show, through scattered examples, that even epigraphy can appear in unexpected guises and ways, that can generate curiosity and interest. One might assume-with good reason-that scratched 
and fragmentary words written in ancient alphabet and languages which are often difficult to read and to understand are not exactly the first thought for those who walk through museums, expositions and archaeological areas. To quote the title of the paper by Laura Löser recently published in the Proceedings of the First EAGLE International Conference: 'Epigraphy, who cares?'37 Well, the process of user engagement developed thanks to cooperation with Wikimedia is showing that people do care: in only a few months, about 800 'external' users have been adding comments, asking questions, collaborating in different ways about the images posted in Wikimedia Commons and identified as ancient inscriptions. So, once again, to quote Stacy Sullivan, Google's Chief Cultural Officer, 'If you engage people, they will amaze you.'. In this framework of scientific and civic issues, the EAGLE project, with its concentric organization and collaborative spirit, has the ambitious objective to become, in the field of epigraphy, not just a mere working tool, but a real resource intended for all citizens, be they scholars or not: academic research will benefit of the portal's services and content curation; important parts of our cultural heritage will be collected and preserved in a digital archive; but at the same time EAGLE will also work as social media 'hub', where users can share experiences of personal 'discovery' of ancient inscriptions in unexpected places (books, sites, films).

\section{Conclusions}

Any form of public engagement, if correctly presented and supported by a preliminary research, is not to be considered just a 'sale' of the scientific knowledge. On the contrary, arising consciousness of the importance of our archaeological heritage, and of the classical studies that help us to understand it, should be part of the academics job. In this sense, the European projects that always require a whole series of dissemination activities are somehow starting to change the traditional approach to this matter.

One may argue that, in times of social and economic difficulty such as ours, ancient epigraphy is not exactly a primary need. But I think that, especially in times of social and economic difficulty, long lasting values like a shared knowledge and a civic approach to cultural heritage maintain and even increase their importance. ${ }^{39}$ Epigraphy may be not a primary need, but, after all...

$O$ reason not the need! Our basest beggars

Are in the poorest thing superfluous:

Allow not nature more than nature needs,

Man's life is as cheap as beast's

(William Shakespeare, King Lear, II, 4) 


\section{Notes}

${ }^{1}$ Vala Afshar: 'Harvard's Chief Digital Officer: 10 Digital Best Practices' Huffington Post 01/31/2014: <http://www.huffingtonpost.com/vala-afshar/ harvards-chief-digital-of_b_4701663.html>.

${ }^{2}$ Europeana EAGLE Project: <http://www.eagle-network.eu>.

3 These databases are: Epigraphic Database Bari (EDB), Epigraphic Database Heidelberg (EDH), Epigraphic Database Roma (EDR) and Hispania Epigraphica Online (HEpOl).

${ }^{4}$ Online at US Epigraphy Project, 'Inscription: KY.Lou.SAM.L.1929.17.662': $<$ http://usepigraphy.brown.edu/projects/usep/inscription/KY.Lou. SAM.L.1929.17.662>.

${ }^{5}$ Online at Epigraphic Database Roma, 'EDR135710': <http://www. edr-edr.it/edr_programmi/res_complex_comune.php?do=book\&id_ $\mathrm{nr}=\mathrm{edr} 135710>$.

${ }^{6}$ On this subject see Mimmo 2012 and Pio et al. 2014.

${ }^{7}$ For a complete description of the consortium, see 'Who we are': <http:// www.eagle-network.eu/about/who-we-are/>.

${ }^{8}$ Europeana Collection: $<\mathrm{http} / / /$ europeana.eu/portal/ $>$.

${ }^{9}$ Pelagios Project: $<$ http://pelagios-project.blogspot.it/>.

${ }^{10}$ Ashmolean Latin Inscriptions: <http://www.ashmolean.org/ashwpress/ latininscriptions/>; see also Masseglia 2014.

${ }^{11}$ Attice Inscriptions Online: <https://www.atticinscriptions.com/>.

${ }^{12}$ As pointed out in The European Charter for Researchers: $<$ http://ec.europa. eu/euraxess/index.cfm/rights/europeanCharter $>$.

${ }^{13}$ Europeana 1914-1918, "Add your story": <http://www.europeana1914-1918. eu/en/contributor $>$.

$14<$ http://www.edr-edr.it/edr_programmi/res_complex_comune. php?do=book\&id_nr=edr102733 $>$. Compare also CIL, VI $25611=<$ http:// www.edr-edr.it/edr_programmi/res_complex_comune.php?do=book\&id_ $\mathrm{nr}=\mathrm{edr} 151314>$, that seems to have shared the same destiny.

$15<$ http://www.edr-edr.it/edr_programmi/res_complex_comune.php?do= book\&id_nr=edr150240>.

${ }^{16}$ On this episode see Cooley 2014: 342.

17 "Le bombe dellestate ' 93 e la trattativa con lo stato," available: <http://www. beatopadrepuglisi.it/2014/10/le-bombe-dellestate-93-e-la-trattativa.html> (last accessed February 2016).

${ }^{18}$ Corresponding to CIL, VI $1123=40718=<$ http://www.edr-edr.it/edr programmi/res_complex_comune.php?do=book\&id_nr=edr093098 $>$.

${ }_{19}$ Specifically CIL, VI 32164, available: <http://www.edr-edr.it/edr_ programmi/res_complex_comune.php?do=book\&id_nr=edr151433 $>$.

${ }^{20}$ For example CIL, VI 13493, available: <http://www.edr-edr.it/edr programmi/res_complex_comune.php?do=book\&id_nr=edr131538>; or 
CIL, VI 7598, available: <http://www.edr-edr.it/edr_programmi/res_complex_comune.php?do=book\&id_nr=edr131539>.

${ }^{21}$ Orlandi 2013, 335, with images at 336-337.

${ }^{22}$ CIL, VI 21312, available: <http://www.edr-edr.it/edr_programmi/res_ complex_comune.php?do=book\&id_nr=edr151412>.

${ }^{23}$ On this particular aspect Mandarano 2014, See also Donnini 2014.

24 'Stories'; available: <http://www.eagle-network.eu/stories/>.

25 More about the EAGLE Mobile Application and the Storytelling Application in Orlandi et al. 2014, and Amato et al. 2014. For another application based on image recognition and storytelling, see e.g. Mazzanti et al. 2014.

26 "The Fun Theory 1 - Piano Staircase"; available: <https://youtu.be/ SByymar3bds $>$.

${ }^{27}$ IGRRP, III 1339 = <http://edh-www.adw.uni-heidelberg.de/edh/inschrift/ HD031629>.

${ }^{28}$ Irene Somà, Timeline photograph, available: <https://www.facebook.com/ photo.php?fbid=10151978886059331>.

${ }^{29}$ Eagle Europeana, Timeline photograph, available: <https://www.facebook. com/EAGLEuropeana/photos/a.510572815704156.1073741829. 368159833278789/605067492921354>.

${ }^{30}$ CIL, VI 33976 = <http://www.edr-edr.it/edr_programmi/res_complex_ comune.php?do=book\&id_nr=edr107864>.

${ }^{31}$ CIL, XI $3320=<$ http://www.edr-edr.it/edr_programmi/res_complex_ comune.php?do=book\&id_nr=edr121131>.

32 Benedetti 2014. Cf. a similar case in <http://www.edr-edr.it/edr programmi/res_complex_comune.php?do=book\&id_nr=edr078389>.

33 "Il Mitreo di Sutri - tra sogna e realtà," available: <http://duemmepi. altervista.org/blog/il-mitreo-di-sutri-tra-sogno-e-realta/> (last accessed February 2016).

${ }^{34} \mathrm{CIL}$, VI $40772=<$ http://www.edr-edr.it/edr_programmi/res_complex_ comune.php?do=book\&id_nr=edr073541>.

${ }^{35}$ Rome, Opening Credits, available via YouTube: <https://www.youtube. com/watch?v=LCaDRlog0Rc $>$.

${ }^{36} \mathrm{CIL}$, VI 896 = <http://www.edr-edr.it/edr_programmi/res_complex_ comune.php?do=book\&id_nr=EDR103378>.

37 Löser 2014.

${ }^{38}$ See also the European project Civic Epistemologies, available: <http://www. civic-epistemologies.eu>.

39 See, for example, the contributions collected by Parello and Rizzo 2014. See also the presentation 'Challanging the crisis with digital weapons: The DigilibLT case', by Alice Borgna, available: <https://www.academia. edu/15250546/Challenging_the_crisis_with_digital_weapons_The_ DigilibLT_case>. 


\section{References}

Amato, G., Casarosa, V., Martineau, P., Orlandi, S., Santucci, R. \& Giberti, L. (2014). EAGLE: Europeana Network of Ancient Greek and Latin Epigraphy. A Digital Bridge to the Ancient World. In Ronzino, P. \& Niccolucci, F. (Eds.) (pp. 25-32).

Benedetti, L. (2014). L'Iter Perusinum anno 1643 di Lukas Holste (Mscr. Dresd. F. 191). Quellen und Forschungen aus italienischen Archiven und Bibliotheken, 94: 166-218.

Cooley, A. E. (2014). The emergence of eigraphy in the Kingdom of Naples. Journal of the History of Collecions, 26: 337-353.

Donnini, D. (2014). Gli strumenti per l'emozione con le innovazioni tecnologiche al servizio di una nuova relazione tra il visitatore e i beni culturali. Archeomatica, 3: 26-29.

Löser, L. (2014). Meeting the Needs of Today's Audiences of Epigraphy with Digital Editions. In O. Santucci et al.(Eds.) (pp. 239-254).

Mandarano, N. (2014). Tripadvisor e il marketing culturale. Rimini.

Masseglia, J. (2014). The Ashmolean Latin Inscriptions Project (AshLI). Bringing epigraphic research to museum visitors and schools. In O. Santucci et al. (Eds.) (pp. 221-231).

Mazzanti, P., Casini, M. \& Caldelli, R. (2014). SMartART: un nuovo modo di fruire il Museo. Archeomatica, 3: 30-34.

Mimmo, D. M. (2012). Computational Historiography: Data mining in a century of classics journals. ACM Journal on Computing and Cultural Heritage, 5(1).

Orlandi, S. (2013). Le tracce del passaggio di Alarico nelle fonti epigrafiche. In J. Lipps, C. Machado \& P. von Rummel (Eds.), The Sack of Rome in 410 AD. The Event, its Context and its Impact (pp. 335-351). Wiesbaden.

Orlandi, S., Giberti, L. M. C. \& Santucci, R. (2014a). EAGLE: Europeana network of Ancient Greek and Latin Epigraphy. Making the Ancient Inscriptions accessible. In Lexicon Pilosophicum. International Journal for the History of Texts and Ideas, 2. Retrieved from http://lexicon.cnr.it/

Orlandi, S., Santucci, R., Casarosa V. \& Liuzzo P. (Eds.) (2014b). Information Technologies for Epigraph and Cultural Heirtage. Proceedings of the First EAGLE International Conference, Roma.

Parello. M. C. \& Rizzo, M. S. (Eds.) (2014). Archeologia pubblica al tempo della crisi. Atti delle Giornate gregoriane. VII Edizione (29-30 novembre 2013), Bari.

Pio, G., Fumarola, F., Felle, A. E., Malerba, D. \& Ceci, M. (2014). Discovering Novelty Patterns from the Ancient Christian Inscriptions of Rome. ACM Journal on Computing and Cultural Heritage, 7(4).

Ronzino, P. \& Niccolucci, F. (Eds.) (2014). Horizon2020 and Creative Europe vs Digital Heritage: A European Projects Crossover. Flash News, Pre-Conference Workshop. at Museums and the Web Florence. Retrieved from $<\mathrm{http}: / /$ ceur-ws.org/Vol-1336>. 